\title{
Association of vitamin C status in diabetes mellitus: prevalence and predictors of vitamin C deficiency
}

\author{
Praveen D', Ranadheer Chowdary Puvvada ${ }^{1}$ and Vijey Aanandhi $\mathrm{M}^{2^{*}}$ (D)
}

\begin{abstract}
Background: Vitamin $C$ is one of the most important micronutrient required for various physiological roles in the human system. Evidences suggest that there is an inadequate status of vitamin $\mathrm{C}$ in diabetes mellitus. The objectives of this study is to understand the prevalence of vitamin C deficiency in established type II diabetes mellitus patients and to study the correlation between various variables of diabetes mellitus with serum vitamin $C$ levels.

Methods: A prospective cross-sectional study to assess the prevalence of vitamin C deficiency was carried out in diabetes patients. Fasting blood sugar levels, glycated hemoglobin, serum malondialdehyde levels, and lipid profile levels were correlated with serum vitamin C levels.

Results: The prevalence rate of hypovitaminosis C is found to be $55.13 \%$ among the enrolled patients. There is a significant increase in the systolic blood pressure levels in patients with inadequate as well as deficient vitamin $C$ levels $(p<0.05)$. Inverse relationship exists between fasting blood sugar and vitamin $C$ levels $(p<0.001)$. Similarly total cholesterol levels were also inversely related to the vitamin $C$ levels $(p=0.0031)$. Body mass index, glycated hemoglobin, and fasting blood sugar levels are important predictors of vitamin $\mathrm{C}$ deficiencies.

Conclusion: Vitamin C deficiency is well established among diabetes mellitus patients. Deficiency of vitamin C levels has an impact on the serum malondialdehyde levels suggesting increased oxidative stress. The higher oxidative stress would have led to increase in glycated hemoglobin. Further research must be carried out to understand the beneficial effects of vitamin $\mathrm{C}$ supplementation in diabetes mellitus.
\end{abstract}

Keywords: Ascorbic acid, Diabetes mellitus, Glycemic control, Hypovitaminosis C

\section{Background}

The role of ascorbic acid in various metabolic diseases has been researched upon ever since its discovery. Ascorbic acid is an important vitamin that has well established biological role due its antioxidant nature. The human population is unable to produce their own ascorbic acid, and hence, it must be strictly obtained from the dietary sources [1]. Vitamin $\mathrm{C}$ rich foods are pretty

\footnotetext{
* Correspondence: hodpchemistry@velsuniv.ac.in

${ }^{2}$ Department of Pharmaceutical Chemistry and Analysis, School of Pharmaceutical Sciences, Vels Institute of Science Technology and Advanced Studies, Chennai, India

Full list of author information is available at the end of the article
}

common and regularly consumed in our daily diet [2]. Inadequacy occurs due to the excessive consumption of vitamin $C$ in destabilizing the free radicals. In all metabolic illnesses such as diabetes, there is an inadequate vitamin $C$ serum concentration.

One of the most common diseases affecting the global population is diabetes mellitus. Diabetes mellitus has an extensive pathology especially the mechanism involving oxidative stress is still complex. The generation of the reactive oxygen species (ROS) such as superoxide anions could damage the islets of Langerhans particularly the $\beta$ cells resulting in reduced insulin release. These ROS affects the secondary signal transducers such as protein

\section{Springer Open}

(c) The Author(s). 2020 Open Access This article is licensed under a Creative Commons Attribution 4.0 International License, which permits use, sharing, adaptation, distribution and reproduction in any medium or format, as long as you give appropriate credit to the original author(s) and the source, provide a link to the Creative Commons licence, and indicate if changes were made. The images or other third party material in this article are included in the article's Creative Commons licence, unless indicated otherwise in a credit line to the material. If material is not included in the article's Creative Commons licence and your intended use is not permitted by statutory regulation or exceeds the permitted use, you will need to obtain permission directly from the copyright holder. To view a copy of this licence, visit http://creativecommons.org/licenses/by/4.0/. 
kinase $C$ [3]. The activation of such signal transducers interfere with insulin activity leading to the development of insulin resistance. Studies have suggested vitamin C deficiency is far more prevalent in pre-diabetics and established diabetes mellitus patients when compared to non-diabetic individuals [4].

There are several reports that stated the use of ascorbic acid as a supplementation in the prevention of disease progression and their complications [5]. The objectives of this study is to understand the prevalence of vitamin $\mathrm{C}$ deficiency in established type II diabetes mellitus patients, to study the correlation between various variables of diabetes mellitus with serum vitamin $C$ levels.

\section{Methods}

\section{Study design}

A prospective cross-sectional study was carried out in a tertiary care teaching hospital between September 2018 and August 2019. Sample size was calculated using Raosoft online calculator. With a population size of $1200 \mathrm{pa}-$ tients (derived from the prevalence data of the hospital in the previous year prior to the study) and a confidence interval of $95 \%$, the sample size was calculated to be 292 [6]. The study was approved by the institutional ethics committee VISTAS-SPS/IEC/2018/1/07. All the study participants have provided a written informed consent for their willingness to participate in this study.

\section{Study participants}

Patients who are 18 years or older and diagnosed with type II diabetes mellitus characterized by a fasting blood sugar level between $126 \mathrm{mg} / \mathrm{dL}$ and $250 \mathrm{mg} / \mathrm{dL}$ and glycated hemaglobin level below $9 \%$ were included for the study as higher level may require multiple drug therapy. Patients who are only on metformin were included as other oral hypoglycemic agents may affect the metabolism of ascorbic acid [7]. Participants who were unable to give informed consent, patients who had previous experience of cardiovascular events were excluded. Pregnant and nursing women were also excluded from the study.

A specially designed data extraction form is used to obtain the preliminary data such as demographics like age, sex, family history of diabetes mellitus, qualification, smoking history, alcoholism, duration of diabetes, and past medical history were recorded. Anthropometric measurement such as height and body weight was recorded, and they were used to determine the body mass index (BMI). The glycemic status parameters such as fasting blood glucose (FBS) and glycated hemoglobin (HbA1C) were recorded using conventional methods.

Table 1 Baseline characteristics of selected participants $(n=292)$

\begin{tabular}{|c|c|c|c|}
\hline Parameter & $\begin{array}{l}\text { Sufficient (serum } \\
\text { vitamin } C>0.6 \mathrm{mg} / \mathrm{dL} \text { ) }\end{array}$ & $\begin{array}{l}\text { Insufficient (serum vitamin } \\
\text { C } 0.6 \text { to } 0.3 \mathrm{mg} / \mathrm{dL} \text { ) }\end{array}$ & $\begin{array}{l}\text { Deficient (serum vitamin } \\
C<0.3 \mathrm{mg} / \mathrm{dL} \text { ) }\end{array}$ \\
\hline Number of patients, $n(\%)^{\#}$ & $56(19.17)^{a}$ & $75(25.68)^{a}$ & $161(55.13)^{b}$ \\
\hline Male, $n(\%)$ & $32(57.14)$ & $51(68.00)$ & $91(56.52)$ \\
\hline Female, $n(\%)$ & $24(42.86)$ & $24(32.00)$ & $70(43.48)$ \\
\hline Age in years & $47.41 \pm 4.51$ & $49.15 \pm 5.16$ & $44.22 \pm 8.14$ \\
\hline Family history, n (\%) & $21(37.5)$ & $34(45.33)$ & $104(64.59)$ \\
\hline $\begin{array}{l}\text { Duration of diabetes (years) } \\
\text { mean } \pm \text { SEM }\end{array}$ & $2.4 \pm 1.5$ & $2.9 \pm 1.4$ & $2.6 \pm 1.9$ \\
\hline \multicolumn{4}{|l|}{ Qualification } \\
\hline Elementary school/no qualification, $n(\%)$ & $7(12.5)$ & $8(10.66)$ & $31(19.25)$ \\
\hline Secondary school, $n$ (\%) & $11(19.64)$ & $21(28.00)$ & $62(38.50)$ \\
\hline Graduate, $n(\%)$ & $20(35.71)$ & $22(29.33)$ & $50(31.05)$ \\
\hline Post graduate, $n(\%)$ & $18(32.14)$ & $24(32.00)$ & $18(11.18)$ \\
\hline \multicolumn{4}{|l|}{ Smoking status } \\
\hline Smoker, $n(\%)$ & $14(25.00)$ & $24(32.00)$ & $47(29.19)$ \\
\hline Non-smoker, n (\%) & $40(71.42)$ & $46(61.33)$ & $104(64.59)$ \\
\hline Previous smoking history, $n(\%)$ & $2(03.57)$ & $5(06.66)$ & $10(06.21)$ \\
\hline BMI $\left(\mathrm{kg} / \mathrm{m}^{2}\right)^{*}$ & $24.1 \pm 1.5^{\mathrm{a}}$ & $24.9 \pm 1.6^{\mathrm{a}}$ & $27.9 \pm 1.1^{b}$ \\
\hline Systolic blood pressure $(\mathrm{mmHg})^{*}$ & $117.6 \pm 11.2^{a}$ & $129.4 \pm 10.5^{b}$ & $134.6 \pm 7.1^{b}$ \\
\hline Diastolic blood pressure (mmHg) & $74.3 \pm 7.1$ & $81.2 \pm 5.4$ & $89.6 \pm 4.2$ \\
\hline
\end{tabular}

All values are mentioned as mean \pm SEM unless stated otherwise

${ }^{*} p<0.05$ on performing ANOVA followed by a post hoc analysis. The same alphabet on superscript denotes no significant difference after performing inferential statistics ${ }^{\#} p<0.05$ on performing chi squared test 
Table 2 Glycemic control, cardiovascular risk, and oxidative stress markers of selected participants $(n=292)$

\begin{tabular}{|c|c|c|c|}
\hline Parameter & $\begin{array}{l}\text { Sufficient (serum } \\
\text { vitamin } C>0.6 \mathrm{mg} / \mathrm{dL} \text { ) }\end{array}$ & $\begin{array}{l}\text { Insufficient (serum } \\
\text { vitamin C } 0.6 \text { to } 0.3 \mathrm{mg} / \mathrm{dL} \text { ) }\end{array}$ & $\begin{array}{l}\text { Deficient (serum } \\
\text { vitamin } C<0.3 \mathrm{mg} / \mathrm{dL} \text { ) }\end{array}$ \\
\hline \multicolumn{4}{|l|}{ Glycemic control markers } \\
\hline Fasting blood sugar, mg/dL* & $154.2 \pm 10.5^{\mathrm{a}}$ & $181.4 \pm 10.2^{b}$ & $196.4 \pm 8.4^{b}$ \\
\hline $\mathrm{HbA} 1 \mathrm{C}, \%{ }^{*}$ & $7.1 \pm 0.2^{\mathrm{a}}$ & $8.1 \pm 0.3^{b}$ & $8.1 \pm 0.2^{b}$ \\
\hline \multicolumn{4}{|l|}{ Cardiovascular risk markers } \\
\hline High-density lipoprotein (HDL), mg/dl* & $47.2 \pm 2.6^{a}$ & $43.2 \pm 2.1^{\mathrm{ab}}$ & $37.6 \pm 1.9^{b}$ \\
\hline Triglycerides (TG), mg/dL ${ }^{*}$ & $159.6 \pm 2.2^{\mathrm{a}}$ & $154.6 \pm 1.5^{\mathrm{a}}$ & $194.5 \pm 6.1^{b}$ \\
\hline Total cholesterol (TC), mg/dL* & $187.4 \pm 4.4^{\mathrm{a}}$ & $191.2 \pm 2.6^{\mathrm{a}}$ & $214.5 \pm 1.94^{b}$ \\
\hline Framingham Risk Score* & $15.4 \pm 1.9^{a}$ & $17.2 \pm 1.6^{\mathrm{ab}}$ & $19.4 \pm 2.1^{b}$ \\
\hline \multicolumn{4}{|l|}{ Oxidative stress marker } \\
\hline Malondialdehyde, $\mu \mathrm{mol} / \mathrm{L}^{*}$ & $0.84 \pm 0.21^{\mathrm{a}}$ & $2.15 \pm 0.54^{b}$ & $2.96 \pm 0.94^{b}$ \\
\hline
\end{tabular}

All values are mentioned as mean \pm SEM unless stated otherwise

${ }^{\mathrm{ab}}$ No significant variation when compared to both the groups

${ }^{*} p<0.05$ on performing ANOVA followed by a post hoc analysis. The same alphabet on superscript denotes no significant difference after performing inferential statistics

Cardiovascular risk assessment parameters such as systolic blood pressure (SBP), high density lipoprotein (HDL), total cholesterol (TC), and triglycerides (TG) were analyzed. From these available data, Framingham Risk Score was calculated. Framingham Risk Score is a Canadian risk assessment score for 10-year cardiovascular risk projection. Oxidative stress markers such as malondialdehyde levels were also analyzed.

Serum vitamin $C$ levels were analyzed from the blood which was acidified with a chelator and perchloric acid and was subjected to automated high performance liquid chromtography (HPLC).

The study participants were counseled by a certified dietician of the hospital to follow a standard diet with required daily allowance of vitamin $C$. The participants were asked to maintain a patient's diary to track the food consumed prior to the collection of blood.

\section{Statistical analysis}

Descriptive statistics were used to analyze the preliminary data in the form of mean \pm SEM. The baseline parameters were analyzed using one-way ANOVA and chi-squared test as appropriate with a significance level of $95 \%$. Pearson correlation was used to correlate the association between each variable in a cohort with serum vitamin $C$ levels. All the univariate analyses used a $p<0.05$ to be considered statistically significant. The statistical analyses were carried out using IBM SPSS (Statistical Programme for social Sciences version 22) and GrapPad prism version 9.0.

\section{Results}

Initially, 359 patients were screened and 292 participants were selected for the study based on the selection criteria participants. The patients were categorized to three groups depending upon their serum vitamin $\mathrm{C}$ levels such as sufficient (serum vitamin $C>0.6 \mathrm{mg} / \mathrm{dL}$ ), Insufficient (serum vitamin $\mathrm{C} 0.6$ to $0.3 \mathrm{mg} / \mathrm{dL}$ ) and deficient (serum vitamin $\mathrm{C}<0.3 \mathrm{mg} / \mathrm{dL}$ ).

It could be inferred from the table 1 that the prevalence rate of hypovitaminosis C is $55.13 \%$. There is a

Table 3 Correlation of variables with vitamin C levels

\begin{tabular}{llll}
\hline Characteristic & Mean \pm SEM & $p$ value & $r$ value (correlation) \\
\hline Age (years) & $45.16 \pm 4.4$ & 0.0828 & 0.2212 \\
BMI $\left(\mathrm{kg} / \mathrm{m}^{2}\right)$ & $26.9 \pm 2.6$ & 0.0461 & $-0.6201^{*}$ \\
Systolic blood pressure $(\mathrm{mmHg})$ & $128.6 \pm 2.2$ & 0.0514 & -0.1104 \\
Diastolic blood pressure (mmHg) & $84.2 \pm 0.5$ & 0.0612 & -0.1721 \\
Duration of diabetes (years) & $2.5 \pm 0.6$ & 0.0979 & 0.1544 \\
Total cholesterol (mg/dL) & $194.1 \pm 4.1$ & 0.0031 & $-0.7191^{*}$ \\
Framingham Risk Score & $18.2 \pm 1.6$ & 0.0321 & -0.6914 \\
Fasting blood sugar (mg/dL) & $188.2 \pm 2.3$ & $<0.001$ & $-0.8056^{* *}$ \\
\hline
\end{tabular}

All values are mentioned as mean \pm SEM unless stated otherwise ${ }^{*} p<0.05$

${ }^{* *} p<0.001$ on performing the two-tailed Pearson correlation 

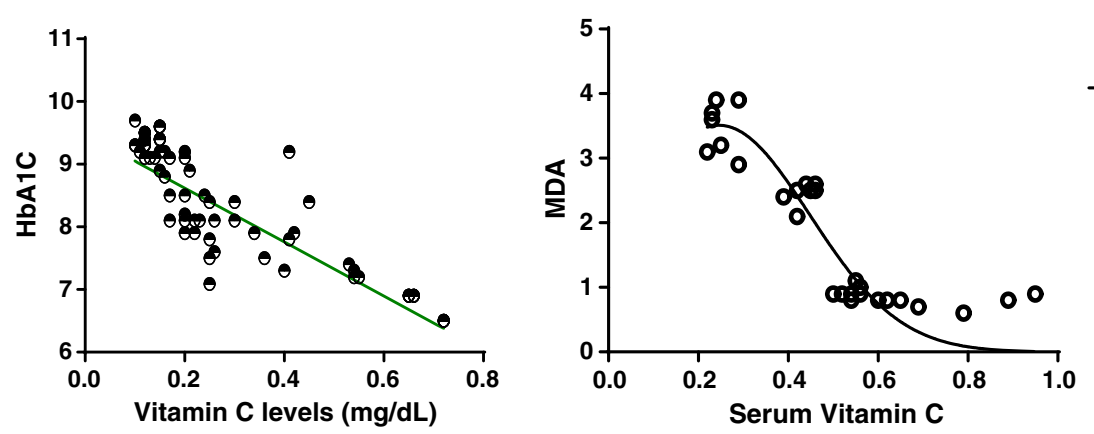

Fig. 1 Correlation between $\mathrm{HbA} 1 \mathrm{c}$, malondialdehyde, and serum vitamin $\mathrm{C}$

significant high systolic blood pressure levels in inadequate as well as deficient groups is seen.

It is evident from Table 2 that cardiovascular risk markers and oxidative stress markers are significantly altered in patients with vitamin $\mathrm{C}$ deficiency.

It can be seen from Table 3 that a significant inverse relationship exists between fasting blood sugar and vitamin C levels. Similarly total cholesterol levels were also inversely related to the vitamin $\mathrm{C}$ levels.

On performing the Pearson correlation between glycated hemoglobin and serum vitamin $C$ levels, $r=$ $0.8741^{* *}$. When correlation analysis was performed between malondialdehyde levels and serum vitamin C levels, $r=-0.8121^{* * *}$.

The glycated hemoglobin has a significant inverse relationship with serum vitamin $C$ levels (Fig. 1). Malondialdehyde which is predominantly scavenged by antioxidants has also a significant inverse relationship with vitamin $C$ levels (Fig. 1).

Although smoking status is an important predictor for vitamin $\mathrm{C}$ deficiencies, it is not significant in the results obtained. Body mass index, glycated hemoglobin, and fasting blood sugar levels are important predictors of vitamin $\mathrm{C}$ deficiencies (Table 4).

\section{Discussion}

It has been observed from our study that there is a prevalence rate of $55.13 \%$ hypovitaminosis $\mathrm{C}$ (deficient vitamin $\mathrm{C}$ status) in type 2 diabetes mellitus patients

Table 4 Linear regression analysis of variables

\begin{tabular}{llll}
\hline Parameter & $r$ & $r^{2}$ & $p$ value \\
\hline Age & 0.2212 & 0.0489 & 0.0828 \\
BMI & 0.6201 & 0.3845 & $0.0461^{*}$ \\
Smoker & 0.6104 & 0.3726 & 0.0511 \\
HbA1C & -0.8741 & 0.7640 & $<0.001^{* *}$ \\
FBS & -0.8056 & 0.6490 & $<0.001^{* *}$ \\
Total cholesterol & -0.7191 & 0.5171 & $0.0031^{*}$ \\
\hline
\end{tabular}

${ }^{*} p<0.05$ is considered significant

${ }^{* *} p<0.001$ is considered extremely significant which is similar to the study by David et al. [8]. Vitamin $\mathrm{C}$ deficiency may further contribute to the microvascular and microvascular complications in diabetes mellitus patients $[9,10]$. It could be seen from our study that lipid profile parameters are significantly higher in the vitamin c deficiency group. Oxidative stress and the impact of reactive oxygen species level contribute to the higher levels of lipids in vitamin $\mathrm{C}$ deficiency status $[4,11]$.

The study showed that there is a significant inverse relationship between the individual predictors such as fasting blood sugar, glycated hemoglobin, high-density lipoproteins, total cholesterol, body mass index, triglycerides, malondialdehyde levels, and vitamin C levels.

Body mass index levels were inversely proportional to the serum vitamin $\mathrm{C}$ concentration. Patients with higher body mass index require higher consumption of ascorbic acid for the regular needs [12]. The fasting blood sugar is inversely proportional to the serum vitamin $C$ levels which is in accordance with the previous results [13, 14].

Malondialdehyde levels are also inversely related to their serum vitamin $C$ levels. In diabetes mellitus, there is an increased impact of reactive oxygen species and free radicals; therefore, there is an increase demand of the antioxidants to scavenge the free radicals [15]. However, the individual consumption must be increased in order to overcome these deficiencies.

Supplementation of vitamin $C$ in diabetes mellitus patients may be beneficial. Vitamin $C$ being water soluble vitamin is at lower risk of hypervitaminosis $C$ when compared to other antioxidant vitamins such as vitamin E which is lipid soluble $[10,16]$. Certain studies predicted that vitamin $\mathrm{C}$ is being excreted through urine [17]. This should be analyzed in human also in the future. Further research is required to assess the beneficial effects of vitamin $C$ supplementation in diabetes mellitus patients in improvement of their glycemic control and prevention of their complications through this potent antioxidant. 


\section{Conclusion}

There is a definite prevalence of vitamin $\mathrm{C}$ deficiency in type 2 diabetes mellitus patients. Also, there is an inverse relationship between the fasting blood sugar levels, body mass index, and vitamin C levels. Significant negative correlation has been observed between glycated hemoglobin levels with serum vitamin $\mathrm{C}$ levels. Vitamin $\mathrm{C}$ is an important antioxidant vitamin that is necessary for scavenging of these free radicals and prevention of further complication of diabetes mellitus. There is a necessity to increase the supply of vitamin $\mathrm{C}$ to diabetes mellitus patients as they may be beneficial in managing the glycemic control and preventing further complications.

\section{Abbreviations}

ANOVA: Analysis of variance; BMI: Body mass index; FBS: Fasting blood sugar; HbA1c: Glycated hemoglobin; HPLC: High performance liquid chromatography; ROS: Reactive oxygen species

\section{Acknowledgements}

The authors are thankful to Vels Institute of Science Technology and Advanced Studies and its management for extending their support and research facilities.

\section{Authors' contributions \\ Concept-P.D; Design-P.D, R.C.P, and M.V.A.; Supervision-M.V.A. Materials_P.D, R.C.P, and M.V.A; Data Collection and/or Processing-P.D, R.C.P, and M.V.A.; Analysis and/or Interpretation-P.D, R.C.P, and M.V.A.; Literature Search-P.D.; Writing -P.D; Critical reviews-R.C.P and M.V.A. The authors have read and approved the manuscript.}

\section{Funding}

Nil

\section{Availability of data and materials}

The datasets used and analyzed during the current study are available from the corresponding author on reasonable request.

\section{Ethics approval and consent to participate}

The study was approved by the institutional ethics committee VISTAS-SPS/ IEC/2018/1/07. All the study participants have provided a written informed consent for their willingness to participate in this study.

\section{Consent for publication}

A consent for publication was obtained from all participants.

\section{Competing interests}

The authors declared that they have no competing interests.

\section{Author details}

${ }^{1}$ School of Pharmaceutical Sciences, Vels Institute of Science Technology and Advanced Studies, Chennai, India. ${ }^{2}$ Department of Pharmaceutical Chemistry and Analysis, School of Pharmaceutical Sciences, Vels Institute of Science Technology and Advanced Studies, Chennai, India.

Received: 20 February 2020 Accepted: 25 May 2020

Published online: 01 July 2020

\section{References}

1. Drouin G, Godin J, Page B (2011) The genetics of vitamin C loss in vertebrates. Curr Genomics 12:371-378

2. Harding AH, Wareham NJ, Bingham SA, Khaw K, Luben R, Welch A et al (2008) Plasma vitamin C level, fruit and vegetable consumption, and the risk of new-onset type 2 diabetes mellitus: the European prospective investigation of cancer-Norfolk prospective study. Arch. Intern. Med 168: 1493
3. Zhang, J., Wang, X., Vikash, V., Ye, Q., Wu, D., Liu, Y.,et al (2016) ROS and ROS-mediated cellular signaling. Oxid Med Cell Long 1-18.

4. Wilson R, Willis J, Gearry R, Skidmore P, Fleming E, Frampton C et al (2017) Inadequate vitamin C status in prediabetes and type 2 diabetes mellitus: associations with glycaemic control, obesity, and smoking. Nutrients 9(9):997

5. Chambial S, Dwivedi S, Shukla K, John P, Sharma P (2013) Vitamin C in disease prevention and cure: an overview. Indian J Clin Biochem. 28(4):314-328

6. Sample Size Calculator by Raosoft, Inc. [Internet]. Raosoft.com. 2019 [cited 31 August 2018]. Available from: http://www.raosoft.com/samplesize. html?nosurvey

7. O'Brien RC, Luo M (1997) The effects of gliclazide and other sulfonylureas on low-density lipoprotein oxidation in vitro. Metabolism 46(12 Suppl 1):22-25

8. Christie-David D, Gunton J (2017) Vitamin C deficiency and diabetes mellitus - easily missed? Diabet Med 34(2):294-296

9. Carr AC, Frei B (1999) Toward a new recommended dietary allowance for vitamin $C$ based on antioxidant and health effects in humans. Am. J. Clin. Nutr 69:1086-1107

10. Garcia-Bailo B, El-Sohemy A, Haddad PS, Arora P, Benzaied F, Karmali M, Badawi A (2011) Vitamins D, C, and E in the prevention of type 2 diabetes mellitus: modulation of inflammation and oxidative stress. Biologics 5:7-19

11. Lykkesfeldt J, Poulsen HE (2010) Is vitamin C supplementation beneficial? Lessons learned from randomised controlled trials. Br. J. Nutr 103:1251-1259

12. Johnston CS, Beezhold BL, Mostow B, Swan PD (2017) Plasma vitamin C is inversely related to body mass index and waist circumference but not to plasma adiponectin in nonsmoking adults. J. Nutr 137:1757-1762

13. Carr AC, Pullar JM, Bozonet SM, Vissers MC (2016) Marginal ascorbate status (hypovitaminosis $\mathrm{C}$ ) results in an attenuated response to vitamin $\mathrm{C}$ supplementation. Nutrients 8:341

14. Girgis C, Christie-David D, Gunton J (2015) Effects of vitamins C and D in type 2 diabetes mellitus. Nutr Diet Suppl 7:21-28. https://doi.org/10.2147/ NDS.S52022

15. Block G, Mangels AR, Patterson BH, Levander OA, Norkus EP, Taylor PR (1999) Body weight and prior depletion affect plasma ascorbate levels attained on identical Vitamin C intake: a controlled-diet study. J. Am. Coll. Nutr 18:628-637

16. Lamb RE, Goldstein BJ (2008) Modulating an oxidative-inflammatory cascade: potential new treatment strategy for improving glucose metabolism, insulin resistance, and vascular function. Int. J. Clin. Pract 62: 1087-1095

17. Choi J, Kim D, Choue R, Lim H (2017) Effects of vitamin C supplementation on plasma and urinary vitamin C concentration in Korean women. Clinical Nutrition Research. 6(3):198

\section{Publisher's Note}

Springer Nature remains neutral with regard to jurisdictional claims in published maps and institutional affiliations.

\section{Submit your manuscript to a SpringerOpen ${ }^{\circ}$ journal and benefit from:}

- Convenient online submission

- Rigorous peer review

- Open access: articles freely available online

High visibility within the field

- Retaining the copyright to your article

Submit your next manuscript at $>$ springeropen.com 